\title{
Tromboprofilaksa kod bolesnika sa atrijalnom fibrilacijom: Da li se snovi ostvaruju?
}

\author{
Tatjana S. Potpara ${ }^{1,2}$ \\ ${ }^{1}$ Klinika za kardiologiju, Klinički centar Srbije, ${ }^{2}$ Medicinski fakultet, Univerzitet u Beogradu
}

$\mathbf{N}$ ezarazna kardiovaskularna epidemija atrijalne fibrilacije (AF) proglašena je još krajem prošlog veka, nepunih sto godina posle prvog formalnog opisa ove aritmije kod ljudi ${ }^{1-3}$. Počev od prvog opisa „čudnovate nepravilnosti pulsa”, AF je prešla dug put od „prihvatljive zamene za fiziološki sinusni ritam" do savremenog shvatanja da je ova srčana aritmija ozbiljna pretnja zdravlju, sa značajnim kardiovaskularnim morbiditetom i mortalitetom (pre svega usled povećanog rizika od ishemijskog moždanog udara i srčane insuficijencije) i sa dalekosežnim socijalnim i ekonomskim implikacijama ${ }^{1-7}$.

AF je u prošlosti najčešće bila povezana sa tri „oze” reumatskom mitralnom stenozom, hipertireozom i aterosklerozom. Danas AF ima drugačiji epidemiološki profil i načešće se javlja kod osoba sa arterijskom hipertenzijom, srčanom insuficijencijom i koronarnom bolešću ${ }^{3}$. Ovu aritmiju trenutno ima oko $2 \%$ populacije odraslih osoba ${ }^{2,8}$, a očekuje se da broj obolelih neprestano raste tokom narednih decenija9

Savremena saznanja o AF rezultat su neprekidnih napora brojnih naučnika i kliničara tokom dugog vremenskog perioda. Dvadeset prvi vek je doneo brojna uzbudljiva otkrića u medicini, a jedno od najznačajnijih u oblasti AF jesu nove alternative oralnoj antikoagulantnoj terapiji antagonistima vitamina $\mathrm{K}$ - direktni inhibitori jednog od faktora koagulacije (trombina ili aktiviranog faktora $X$ ) - non-vitamin K oralni antikoagulansi (NOAK) ${ }^{10}$. Ovi lekovi se primenjuju u fiksnim dozama, deluju brže i kraće od antagonista vitamina $\mathrm{K}$ i nije potrebna rutinska laboratorijska kontrola intenziteta njihovog antikoagulantnog efekta (nema klinički značajnih interakcija sa hranom, a broj relevantnih interakcija NOAK sa drugim lekovima daleko je manji nego kod antagonista vitamina $\mathrm{K})^{11}$. Efikasnost i bezbednost ovih lekova u prevenciji moždanog udara i sistemskih tromboembolija kod bolesnika sa nevalvularnom AF ispitana je u randomizovanim kliničkim studijama impresivne veličine i dizajna, koje su pružile nesumnjivi naučni dokaz o sličnoj efikasnosti i većoj bezbednosti NOAK u odnosu na antagonist vitamina K-varfarin ${ }^{12-15}$. Nekoliko ovih lekova već se koristi u kliničkoj praksi u većini zemalja širom sveta, uključujući i našu zemlju.

U nastojanju da bolesnicima sa AF pružimo što efikasniju i bezbedniju prevenciju moždanog udara i drugih tromboembolijskih komplikacija AF, postepeno učimo kako da što bolje koristimo NOAK u kliničkoj praksi. U tom procesu suočavamo se i sa brojnim izazovima. Prvi put imamo mogućnost višestrukog izbora, a količina informacija o optimalnoj prevenciji tromboembolijskih komplikacija AF svakodnevno raste velikom brzinom. Sa druge strane, sve je veći broj bolesnika sa AF i kompleksnim komorbiditetima koji istovremeno povećavaju i tromboembolijski i hemoragijski rizik, a kod takvih bolesnika nije uvek lako odlučiti koja terapija je najprimerenija.

Ubrzani razvoj u oblasti tromboprofilakse u AF doneo je i poboljšanje kvaliteta oralne antikoagulantne terapije antagonistima vitamina $\mathrm{K}$ u odnosu na vreme od pre desetak godina, a sve više se razvijaju i nefarmakološke metode za prevenciju tromboembolijskih komplikacija AF (okluzija aurikule leve pretkomore). Ipak, dugoročno gledano, sigurno je da će NOAK biti okosnica optimalne tromboprofilakse kod većine bolesnika sa AF, dok će antagonisti vitamina $\mathrm{K}$ i nefarmakološke metode biti rezervisani za relativno mali broj bolesnika.

U cilju unapređenja znanja o optimalnoj prevenciji ishemijskog moždanog udara i sistemskih tromboembolija kod bolesnika sa AF, Udruženje atrijalne fibrilacije Srbije je organizovalo Prvi međunarodni sastanak o tromboprofilaksi u AF, na kome kao predavači učestvuju vrhunski svetski stručnjaci iz ove oblasti. U ovom dodatku časopisa Srce i krvni sudovi nalaze se pregledni radovi koji sumiraju savremena saznanja o NOAK i njihovoj primeni u kliničkoj praksi, kao i sažeci originalnih radova - prikazi kompleksnih slučajeva tromboprofilakse u AF iz kliničke prakse učesnika sastanka.

\section{Literatura}

1. Prystowsky EN. The history of atrial fibrillation: the last 100 years. J Cardiovasc Electrophysiol 2008; 19: 575-82.

2. Ball J, Carrington MJ, McMurray JJ, Stewart S. Atrial fibrillation: profile and burden of an evolving epidemic in the 21st century. Int J Cardiol 2013; 167: 1807-24.

3. Camm AJ, Lip GY, De Caterina R et al. 2012 focused update of the ESC Guidelines for the management of atrial fibrillation: an update of the 2010 ESC Guidelines for the management of atrial fibrillation. Developed with the special contribution of the European Heart Rhythm Association. Eur Heart J 2012; 33: 2719-47.

4. Benjamin EJ, Wolf PA, D'Agostino RB et al. Impact of atrial fibrillation on the risk of death: the Framingham Heart Study. Circulation 1998; 98: 946-52.

5. Wang TJ, Larson MG, Levy D et al. Temporal relations of atrial fibrillation and congestive heart failure and their joint influence on mortality: the Framingham Heart Study. Circulation 2003; 107: 2920-5.

Kontakt osoba: Dr Sci Dr Med Tatjana Potpara, FESC., Klinika za kardiologiju, Klinički centar Srbije, Višegradska 26, 11000 Beograd, Srbija.

Tel: +381 11 3616319, Fax: +381 11 3616319; Email: tanjapotpara@gmail.com; tatjana.potpara@mfub.bg.ac.rs 
6. Wolf PA, Abbott RD, Kannel WB. Atrial fibrillation as an independent risk factor for stroke: the Framingham Study. Stroke 1991; 22: 983-8.

7. Potpara TS, Polovina MM, Licina MM et al. Predictors and prognostic implications of incident heart failure following the first diagnosis of atrial fibrillation in patients with structurally normal hearts: the Belgrade Atrial Fibrillation Study. Eur J Heart Failure 2013; 15: 415-24.

8. Heeringa J, van der Kuip DA, Hofman A et al. Prevalence, incidence and lifetime risk of atrial fibrillation: the Rotterdam study. Eur Heart J 2006; 27: 949-53.

9. Go AS, Hylek EM, Phillips KA et al. Prevalence of diagnosed atrial fibrillation in adults: national implications for rhythm management and stroke prevention: the AnTicoagulation and Risk Factors in Atrial Fibrillation (ATRIA) Study. JAMA 2001; 285: 2370-5.
10. Potpara TS, Lip GY. Novel oral anticoagulants in non-valvular atrial fibrillation. Clin Haematol 2013; 26: 115-29.

11. Husted S, De Caterina R, Andreotti F et al. Non-vitamin K antagonist oral anticoagulants (NOACs): No longer new or novel. Thromb Haemost 2014; 111: 781-2.

12. Connolly SJ, Ezekowitz MD, Yusuf S et al. Dabigatran versus warfarin in patients with atrial fibrillation. N Engl J Med 2009; 361: 1139-51.

13. Patel MR, Mahaffey KW, Garg J et al. Rivaroxaban versus warfarin in nonvalvular atrial fibrillation. N Engl J Med 2011; 365: 883-91.

14. Granger CB, Alexander JH, McMurray JJ et al. Apixaban versus warfarin in patients with atrial fibrillation. N Engl J Med 2011; 365: 981-92.

15. Giugliano RP, Ruff CT, Braunwald E et al. Edoxaban versus warfarin in patients with atrial fibrillation. N Engl J Med 2013; 369: 2093-104. 